\title{
Black Doctors and Discrimination under South Africa's Apartheid Regime
}

\author{
ANNE DIGBY* \\ Centre for Health, Medicine and Society, Oxford Brookes University, Oxford OX3 OBP, UK
}

\begin{abstract}
This article discusses an under-researched group and provides an analytical overview of the comparative experiences of African, Indian and Coloured doctors at South African universities during the apartheid era. It probes diversity of experience in training and practice as well as gendered differentiation amongst black students before going on to discuss the careers and political activism of black doctors as well as the impact of recent transformational change on their position. It briefly assesses how singular this South African experience was.
\end{abstract}

Keywords: Black Doctor, Racial Discrimination, Apartheid, South Africa, Medical Training, Medical Profession

This article aims to probe the extent of differentiation and diversity of experience for the largely overlooked group of black doctors in training and practice under the apartheid regime and briefly assesses how singular this South African experience was within an international context. The subject of black doctors and apartheid has been underresearched, although it has received minor historiographical attention in institutional histories, ${ }^{1}$ institutional reconciliation hearings, ${ }^{2}$ specialist studies of black professional

* Email address for correspondence: adigby@brookes.ac.uk

I am grateful to Lukas Spiropoulis and Karen Thomson for research assistance and to the late Dr Anvir Adam, Dr Harriet Deacon, Professor K.P. Mokhobo, Professor Howard Phillips, Professor Krishna Somers, and Dr Helen Sweet for assistance with material and/or with interviews.

${ }^{1}$ M. Shear, Wits: A University in the Apartheid Era (Johannesburg: University of Witwatersrand Press, 1996); B.K. Murray, Wits. The Open Years. A History of the University of Witwatersrand, 1939-59 (Johannesburg: University of Witwatersrand Press, 1997); E.H. Brookes, A History of the University of Natal (Pietermaritzburg: University of Natal Press, 1966); H. Phillips, The University of Cape Town. The Formative Years, 1918-1948 (Cape Town: University of Cape Town Press, 1993).

2 J. Browde, P. Mokhobo and E. Jassat, Report Submitted to the University of Witwatersrand Faculty of Health Sciences Internal Reconciliation Commission (Johannesburg: University of Witwatersrand Medical School, 1988); University of Natal Medical School. Reconciliation Graduation Booklet, 1995 (Durban: Indicator Press, 1995); E. van Heyningen, 'UCT Medical School: Truth and Reconciliation, the Historical Context' (unpublished paper, n.d.). 
experience, ${ }^{3}$ as well as autobiographical accounts. ${ }^{4}$ Despite this, the history of the Medical University of Southern Africa's (MEDUNSA) production of one of the largest body of black medical graduates has been neglected, an omission that this paper seeks to redress. What has also been lacking in the historiography is a comparative framework and this article provides an analytical overview of the sites of medical training.

It is acknowledged that language itself is a problematic and sensitive issue; in this article the term black is used to include Africans, Indians and Coloured (mixed race) individuals as determined by the parameters of the 1950 Population Registration Act. ${ }^{5}$

That the future training of black doctors should be given in South Africa and not overseas was recommended by government reports in 1928 and 1939. ${ }^{6}$ The Second World War meant that training abroad became almost impossible, thus precipitating decisions by two English-speaking, historically white institutions to admit black students at the Universities of Witwatersrand (Wits) in 1941 and Cape Town (UCT) in 1943. The election of an apartheid government in 1948 meant, as Welsh comments, that 'apartheid would entrench and extend' what was already 'a comprehensively, racialised, segregated state'. In consequence, a segregated black medical faculty at the University of Natal (UNB) was created in 1951 whilst black student entry to historically white universities was restricted in 1959 to a small number of permit holders. Contemporary official attention then focused on the need for additional black healthcare personnel for Bantustans following a second stage in the grand apartheid design from 1969 when nine ethnically based 'homelands' or Bantustans were created. In 1977 a second training site for black medical students was set up - MEDUNSA - and a third in 1986 at the University of Transkei. The professional education of several generations of black doctors was thus structured into an ideological paradigm of racial segregation.

Black doctors and apartheid is a politicised topic raising issues of racial discrimination, institutional coercion and personal oppression. The contested area of South Africa's recent past requires the historian to critically consider a wide but scattered and fragmentary range of information, both qualitative and quantitative. This includes official documentation (commissions of inquiry, central governmental, provincial, and neglected Bantustan reports), institutional records (encompassing those of universities and hospitals) as well as personal sources from individual doctors. The use of post-apartheid interviews facilitates a nuanced view, although it is recognised that individual memory is selective and that personal subjectivity responds to the political climate of the present as well as of the past.

\footnotetext{
${ }^{3}$ I.S. Monamodi, 'Medical Doctors under Segregation and Apartheid. A Sociological Analysis of Professionalization among Doctors in South Africa, 1900-1980' (unpublished PhD thesis: Indiana University, 1996); V. Noble, 'Doctors Divided: Gender, Race and Class Anomalies in the Production of Medical Doctors in Apartheid South Africa, 1948-1994' (unpublished PhD thesis: University of Michigan, 2005); V. Noble, 'A Medical Education with a Difference. A History of the Training of Black Student Doctors in Social, Preventive and Community-Oriented Primary Health Care at the University of Natal Medical School, 1940-1960', South African Historical Journal 61, 3 (2009), 550-74; S. Horwitz, “A Phoenix Rising”: A Social History of Baragwanath Hospital, Soweto, South Africa, 1942-1900' (unpublished D. Phil. thesis: University of Oxford, 2006).

${ }^{4}$ W. Pick, The Slave has Overcome (Cape Town: privately published by author, 2007); M. Ramphele, Across Boundaries: The Journey of a South African Woman Leader (New York: Feminist Press, 1995).

${ }^{5}$ G.T.H. Ellison and T. de Wet, "The Use of "Racial" Categories in Contemporary South African Health Research', South African Medical Journal, 87, 12 (1997), 1671-9.

${ }^{6}$ South African government papers, UG 35-1928, [Loram] Inquiry into Training of Natives in Medicine; UG 25-1939, Report on Medical Training in South Africa, ch. VI.

${ }^{7}$ D. Welsh, The Rise and Fall of Apartheid (Johannesburg: Jonathan Ball, 2009), 47.
} 
This article begins by examining the implications of the disadvantaged schooling of black students before investigating the differential impact of institutional growth on numbers of African, Indian and Coloured medical graduations, weighing up the impact of discriminatory training in segregated institutions and assessing consequent constraints on professional careers. It goes on to evaluate responses to apartheid discrimination, including individual political activism and more recent societal responses through transformation and reconciliation.

\section{Disadvantaged Backgrounds}

'We are from humble beginnings; disadvantaged and the odds heavily against us.... We came from very poor schooling'. ${ }^{8}$ The very earliest black doctors had been comparatively well served by mission schools, but after the apartheid legislation of the Bantu Education Act of 1953 closed these establishments, African aspirants to a professional future were penalised. Schooling was frequently characterised by daily double sessions, overcrowded classes, high pupil-teacher ratios, low-paid and poorly qualified teachers and a dearth of scholarship opportunities, and so most schooling may 'seriously handicap the African as a university student'. 9 Only a small number of outstanding high schools with dedicated teachers existed. ${ }^{10} \mathrm{~A}$ few parents were sufficiently affluent to use good boarding schools in Swaziland or Lesotho and later differentials amongst black medical students resulted from these kind of class differences. ${ }^{11}$ The scientific and pre-clinical courses offered by Fort Hare (a tertiary institution set up in 1916 for black students) also enabled some students to bridge the gap between schooling and the clinical courses in medical school. However, many black students continued to suffer from a linguistic handicap because the language of instruction in medical schools was English or Afrikaans, which was a second or third language for many of them. Geographical inequity also impacted because many Africans had homes remote from the first black medical school in Natal. The creation of MEDUNSA lessened this geographical handicap and almost two-thirds of MEDUNSA's students were drawn from neighbouring areas in the Transvaal or northern Bantustans. ${ }^{12}$

Deans of medical schools stated that 'We find ourselves fatally hampered by inadequate (primary and high) schools for Africans', and that 'the dropout rate among African medical students is alarming, and can be directly related to their school education' ${ }^{13}$ At the Natal Medical Faculty, Africans struggled more than Indians or Coloureds due to their limited schooling. ${ }^{14}$ The training period at Natal was extended by a preliminary year but, despite this, little more than half were on schedule with their studies; many failed the second year

\footnotetext{
${ }^{8}$ E-mail to author from the late Dr Anvir Adam, 1937-2011 (MB, BCh Wits, 1964), 15 November 2002.

${ }^{9}$ J.W. Macquarrie, 'The sociological background of the African University Student', in J.V.O. Reid and A.J. Wilmot (eds), Medical Education in South Africa (Pietermaritzburg: University of Natal Press, 1965), 227.

${ }^{10}$ Examples included Morris Isaacson for Africans in Soweto and Harold Cressy, Livingstone and Trafalgar High Schools for Coloureds in Cape Town.

${ }^{11}$ K.S. Broun, Black Lawyers, White Courts (Athens: Ohio University Press, 2000), 55-6.

12 MEDUNSA archives, statistical analysis of graduation ceremony booklets, 1985-90.

${ }^{13}$ E.N. Keen and E.B. Adams quoted by P.V. Tobias in 'Apartheid and Medical Education: The Training of Black Doctors in South Africa', Journal of the National Medical Association, 72,4 (1980), 407.

${ }^{14}$ H.1. Watts, Black Doctors... at the Medical School of Natal, Part 1, The Student (Durban: University of Natal Press, 1975), 38.
} 
after finding anatomy and physiology very challenging. ${ }^{15}$ Overall, only forty-three per cent of students admitted from 1951 to 1970 graduated. ${ }^{16}$

Improved schooling as well as more financial support was required if the number of medical students of colour was to expand. ${ }^{17}$ Low entry standards meant high dropout rates later as they struggled to cope. Dr A. Aziz Aboo commented of his fellows at UCT that 'Many of them came from schools that weren't on a par with the white schools ... fifty per cent of the class of black students, failed in the first year' ${ }^{18}$

MEDUNSA acknowledged that many of its African students came 'from underprivileged communities, where their own education was lacking' ${ }^{19}$ Its rector conceded that 'average standards are not yet on a par with those at white schools' ${ }^{20}$ To counteract this, the institution later identified itself as 'committed to training those previously disadvantaged by Bantu education', 21 with remedial measures including outreach for matriculating school students, training orientation on campus, mentoring of junior by senior students, as well as supplementary instruction. ${ }^{22}$ As a result, a high initial failure rate did not lead to an excessive dropout rate. ${ }^{23}$ And the post-apartheid university promised that 'the selection process shall focus on potential to succeed' ${ }^{24}$ so that, whilst conceding that the entry level was lower than for historically white universities, the exit standard was not. ${ }^{25}$ In contrast, at the University of Transkei only eight to twelve per cent of intakes actually graduated in the apartheid and post-apartheid eras. ${ }^{26}$

As elsewhere in the African continent money was a central concern for black medical students. ${ }^{27}$ Wits students set up an African Medical Scholarship scheme to replace a short-lived government bursary scheme ${ }^{28}$ And at Natal, fifteen government bursaries were created in 1951, gradually increasing to 143 by 1971, when as many as eighty-five per cent of African students held them. ${ }^{29}$ Under these bursaries half the loan was remitted if the student successfully finished the course and, until 1961, the remainder was conditional on service in the public health system. A few provincial bursaries existed, ${ }^{30}$ but these had to be repaid or, as one recollected, you had to enter public service in a remote hospital. ${ }^{31}$

\footnotetext{
15 Watts, ibid., I, 7, 15, 37, table 4 from a sample from the 1969 entry; Noble, 'Doctors Divided', 90-1.

${ }^{16}$ Watts, op. cit. (note 14) I, 37.

17 South African government papers, RP 38-1976, Inquiry into Coloured Population Group [Theron Inquiry], 240 .

18 Interview with Dr A.A. Aboo (MB, CHB, UCT, 1975), 4 May 2006.

19 'A different breed', in MEDUNSA Yearbook 1993/4 (MEDUNSA: Bureau for Public Relations, 1994), 44.

${ }^{20}$ F.P. Retief, 'The Medical University of Southern Africa after 5 years', South African Medical Journal, 62, 11 (1982), 845.

21 'A proud heritage', in MEDUNSA Yearbook, 1996/7 (MEDUNSA: Bureau for Public Relations, 1997), 17.

22 MEDUNSA Yearbooks, ibid., op. cit. (notes 19 and 23), 1993-4, 44 and 1996-7, 71; MEDUNSA Medical University of Southern Africa: 20 Years, 1976-1996 (MEDUNSA: Bureau for Public Relations: 1996), 6.

${ }^{23}$ MEDUNSA 20 Years, ibid., 6.

24 'To be admitted to MEDUNSA', in MEDUNSA Yearbook, 1997-8 (MEDUNSA: Bureau for Public Relations, 1998), 80.

25 'Perspective', in MEDUNSA 20 Years, op. cit. (note 22), 5.

${ }^{26}$ M. Breier with A. Wildschut, Doctors in a Divided Society (Cape Town: HSRC, 2006), 75-80.

27 J. Iliffe, East African Doctors (Cambridge: Cambridge University Press, 1998), 71.

28 SAIRR Reports (Johannesburg: SAIRR, 1949-50), 68; (1951-2), 54.

29 SAIRR Reports (Johannesburg: SAIRR, 1950-1), 57; (1969), 24; (1971), 308.

${ }^{30}$ National Archives, Cape Town, HM 323, Memorandum on the Training of Coloured Medical Practitioners, 14 March 1963.

${ }^{31}$ Interview with Professor William Pick (MB, ChB, UCT, 1964), 26 October 2007.
} 
The professional labour market remained skewed with a gross maldistribution of doctors and a conspicuous rural/urban divide. During the eighties and early nineties newly established Bantustans hoped to grow their own supply of doctors and so help alleviate the shortage of rural public sector doctors. As we have seen, the Transkei Bantustan even set up its own medical school. The Bantustans gave bursaries to medical students, with Lebowa giving monthly salaries to ease hardship. ${ }^{32}$ After graduation several Bantustan bursary holders returned to become hospital interns, ${ }^{33}$ but many did not, thus contributing to disillusionment about solving a chronic medical shortage through training. ${ }^{34}$ More generally, a makeshift student economy was strengthened by American organisations such as Medical Education for South African Blacks (MESAB) giving bursaries from 1985, whilst the Mellon Foundation provided black doctoral fellowships. ${ }^{35}$ In addition, piecemeal help might come from a teacher, the local community, or an employer or local professional chipping in with funds.

Although structurally disadvantaged by an inadequate grants system and inferior schooling, hardship was held to be a bracing incentive. One UCT medical student of colour recollected that:

It put me in quite a spot with some of the members of the family, because everybody else was earning their keep. So ... you could not afford to fail, you could not afford to do badly, and what is more, I worked all my holidays ... to raise some funds [so] that I wasn't too much of a drain. ${ }^{36}$

Indeed, MEDUNSA recognised that its students had 'to develop a greater than usual amount of self-discipline and capacity for hard work, and thus initial disadvantages are converted into valuable personal assets'. ${ }^{37}$ Although some black doctors came from professional homes, others were from impoverished backgrounds where fathers were miners or labourers, and mothers were domestic workers or street traders. However, a poverty-stricken beginning might give personal momentum because, as one remarked, a future as a doctor was 'a dream out of poverty. . a way to get oneself out of poverty'. ${ }^{38}$

\section{Numbers and Institutions}

The two English-speaking historically white universities of UCT and Wits made an early contribution to expanding the number of black doctors. ${ }^{39}$ UCT graduated its first black doctors in 1945; subsequently the vast majority of Coloured doctors trained there, with ninety Coloured medical students registered by the 1970 s. $^{40}$ Wits graduated its first black

\footnotetext{
32 Lebowa Report on Health and Social Welfare 1981/2, 2. Bantustan official annual reports are available in the University of Cape Town Library.

33 Gazankulu Report 1982/3, 44; Venda Report 1982, 30-11; Transkei Report 1985-6, 10-122.

34 KwaZulu Report 1992, 52; Venda Report 1985, 39; Bophuthatswana Report 1987, 33; Transkei Report 1989, 28. Research shows reluctance by medical students more generally to work in rural areas unless originally from a country area (R. Pillay, 'Recruitment and Retention of Medical Doctors in Rural South Africa' (unpublished MBA research report: University of Cape Town, 1996).

35 University of Cape Town Administration Archive (hereafter UCTAA), box 8, Minutes of Board of Faculty of Medicine, 21 Septemper 1993.

36 Interview with Dr Ralph Hendrickse (MB. CHB, UCT, 1948), 25 February 1999.

37 'Perspective', in MEDUNSA 20 Years, op. cit. (note 22), 6.

38 Interview with Dr N. Maharaj (MB, CHB, UCT, 1975), 12 December 2006.

${ }^{39}$ The Afrikaans-speaking medical schools at the Universities of Pretoria, Stellenbosch and the Free State were overwhelmingly white.

${ }^{40}$ UCTAA, Minutes of Board of Faculty of Medicine, 4 Septemper 1973, memorandum submitted to the Theron Commission of Enquiry.
} 
medical students in 1946 with, by 1959, a total of eighty-four black graduates - mainly Africans and Indians. From 1959 to 1984 the apartheid state required black individuals to seek ministerial permission to study at Wits or UCT together with a permit to travel. The Dean of UCT Medical School made a point of underlining the provisional status of Coloured students under permit during the 1960s. ${ }^{41}$ One demeaned UCT student recollected that 'as a black student on permit, you felt like a migrant worker'. ${ }^{42}$ Although permits were granted to most 'Asian' or Coloured applicants, less than one in three African applicants were successful. ${ }^{43}$ As a result, between the 1960s and 1970s from one in six to one in seven at Wits, and from one in five to one in eight at UCT were black medical graduates. $^{44}$

In terms of apartheid the University of Natal was anomalous in having a white faculty and students but opening a medical faculty (UNB) for black students in 1951. Its first medical faculty staff included notable progressives such as Sidney and Emily Kark and George Gale, who hoped to implement aspirations to improve the healthcare of the black population developed in the National Health Services Commission of 1942-4. The apartheid government's election in 1948 had stalled the commission's implementation whilst financial stringency by the apartheid state undercut attempts to fund the Durban faculty at a level ensuring equivalent standards to white medical faculties. ${ }^{45}$ That apartheid had blighted early utopian aspirations for UNB was indicated by the emigration of the Karks and Gale before the end of the fifties.

In 1957 the state attempted to downgrade UNB status by removing it from university control, but this was unsuccessful. ${ }^{46}$ A later government attempt to close this medical faculty was blocked by student opposition, the policy rationale having been that all black medics should graduate from MEDUNSA. ${ }^{47}$ By 1991 UNB had produced more than 300 specialists, whilst by 1995 (when its first white undergraduates were admitted), it had graduated 2,700 black doctors. The racial composition of Natal's medical graduates was remarkably uneven in comprising sixty-two per cent Indians, thirty-three per cent Africans, and five per cent Coloureds, ${ }^{48}$ despite the faculty's continuing efforts to prioritise African admissions. ${ }^{49}$

Critics perceived MEDUNSA's creation in 1976-7 as an extension of the ethnic universities concept, although its white rector justified it as 'optimizing opportunities for [all] black applicants' in a situation of 'a dire need' for trained black healthcare workers. ${ }^{50}$ Initial fears that MEDUNSA's location thirty miles north of Pretoria meant that it would become an ethnically Tswana university were allayed both by early enrolments (showing

\footnotetext{
41 A. Digby, H. Phillips with H. Deacon and K. Thomson, At the Heart of Healing. Groote Schuur Hospital, 1938-2008 (Johannesburg: Jacana, 2008), 117-18.

42 University of Cape Town Health Faculty Archives, submission to Institutional Reconciliation Commission (IRC) by Dr R.J. (MB, ChB, 1974).

43 SAIRR Report (Johannesburg: SAIRR, 1980), 373.

44 Tobias, Tobias, op. cit. (note 13), 404-5.

45 Noble, 'Doctors Divided', op. cit. (note 3), 49-50.

${ }^{46}$ In 2000 it was renamed the University of Natal, Nelson R. Mandela School of Medicine.

47 SAIRR Reports (Johannesburg: SAIRR, 1975), 272-3; (1976), 384; (1977), 544.

48 The University of Natal Medical School, 1951-1991. Meeting the Challenge of Change (Durban: University of Natal Press, 1991), 7; Reconciliation, op. cit. (note 2), 4.

${ }^{49}$ B.T. Naidoo, 'A History of the Durban Medical School', South African Medical Journal, 50,9 (1976), 1627.

${ }^{50}$ Retief, op. cit. (note 20), 841, 846.
} 


\begin{tabular}{cccc}
\hline & Coloured & Indian/Asian & African \\
1966 & 10 & 22 & 7 \\
1967 & 17 & 31 & 11 \\
1968 & 19 & 32 & 10 \\
1969 & 12 & 36 & 8 \\
1972 & 19 & 47 & 16 \\
1974 & 25 & 56 & 19 \\
1975 & 21 & 65 & 9 \\
1976 & & & 23 \\
1977 & & & 32 \\
1981 & 18 & 84 & 24 \\
1982 & 11 & 81 & 77 \\
1983 & 22 & 91 & 74 \\
1986 & 16 & 89 & 76
\end{tabular}

Table 1: Graduating black doctors, 1966-86. Source: Annual Reports of South African Institute of Race Relations (SAIRR), supplemented by data in. Tobias, op. cit. (note 13), Table 2.

less than one-fifth of the students were Tswana) and by the expropriation of its teaching hospital of Ga-Rankuwa from Bophuthatswana, the Tswana 'homeland' ${ }^{51}$

MEDUNSA trained almost exclusively African undergraduates, although in 1989 it graduated its first Indian doctor. Graduating its first thirty-four doctors in 1982, the total had grown to 903 by 1996, of whom as many as two-thirds had qualified between 1990 and $1995 .^{52}$ (This single-handed achievement compared well with a South African total of only about 1,000 black lawyers who had qualified from all training institutions by 1994. ${ }^{53}$ ) At post-graduate level white numbers at MEDUNSA were larger than those of Africans, Indians and Coloureds. By 1994 MEDUNSA claimed to have produced 'nearly half of all the black doctors registered with the South African Medical and Dental Council' (SAMDC), with half its graduates working in 'the under-served non-metropolitan areas of the country' ${ }^{54}$ MEDUNSA and Natal thus had a similar track record to the principal black medical schools in the Unites States of America (USA; Howard, Meharry and Morehouse) in being the main training grounds for black doctors. ${ }^{55}$ In 1985 the University of Transkei Medical School was set up within the Bantustan of Transkei to address the shortage of public sector doctors in rural areas. The school had a low entrance requirement and an accompanying very high dropout rate, but grew rapidly to reach an annual intake of about one hundred students. These were overwhelmingly African students. ${ }^{56}$

Until 1982, when MEDUNSA's first graduations came on-stream, the national output of African doctors compared poorly with that of graduating Indian/‘Asian’ doctors, as Table 1 indicates.

\footnotetext{
${ }^{51}$ MEDUNSA archives, graduation ceremony booklets' statistics 1985-90; Retief, op. cit. (note 20), 841-6.

52 'A proud heritage', in MEDUNSA Yearbook, 1996/7, op. cit. (note 21), 17; 'Statistical profile', in MEDUNSA 20 Years, op. cit. (note 22), 27.

53 Broun, op. cit. (note 11), 236.

54 'Medicine makes inroads', in MEDUNSA Yearbook, 1995/6 (MEDUNSA: Bureau of Public Relations, 1996) 21.

${ }^{55}$ M. Moskowitz, 'The Black Medical Schools Remain the Prime Training Grounds for Black Doctors', Journal of Blacks in Higher Education, 5, 45 (1994), 69-76.

56 Breier with Wildschut, op. cit. (note 26), 75-80.
} 


$\begin{array}{lcc}\text { Population } & \text { Mean annual \% } & \text { Mean \% of total population } \\ \text { White } & 85.4 & 17.3 \\ \text { Asian } & 8.4 & 2.9 \\ \text { Coloured } & 3.4 & 9.4 \\ \text { African } & 3.0 & 70.4\end{array}$

Table 2: Graduating doctors belonging to each population group (per 100,000), 1968-77. Source: Tobias, op. cit. (note 13), 399.

The production of doctors was inversely correlated to population groups in South Africa, as Table 2 indicates. ${ }^{57}$ During the first quarter of a century of apartheid the ratios of white and Asian doctors per million white or Asian people grew, whilst those of Coloured and African doctors declined. ${ }^{58}$ An official inquiry in 1976 drew attention to 'an almost incalculable need for more Coloured doctors'. Nevertheless, the ratio of Coloured doctors to population was 1:6,200 and thus much better than the 1:44,400 for Africans. In a more privileged position were 'Asians' (mainly Indians) with 1:900, and whites with 1:400. ${ }^{59}$

\section{Medical Training}

'We silently tolerated the discrimination, indignity and arrogance we confronted in the university, hoping that one day it would change!' recollected one Indian medical graduate from Wits. ${ }^{60}$ Some individuals were handicapped by the psychological strain of being in a very small minority in a white university whilst others suffered from material adversity. Off-campus studying was difficult, as in the case of an Indian student at Wits who recollected, 'my awful living conditions, a cramped house ... shared by three families comprising seven adults and nine children, with no bathroom and sharing one toilet' ${ }^{61}$ Another instance was that of a UCT student living in a crowded backyard dwelling who 'used to study in the car, in the driveway, to get some peace and quiet'. ${ }^{62}$ And even Natal's Alan Taylor Residence for black medical students was situated in a polluted industrial area, had bleak, barrack-like buildings and, until the 1980s, inadequate public transport to the medical school. ${ }^{63}$

Institutionalised apartheid discriminated against black students, interns and registrars. MEDUNSA internships took place at Ga-Rankuwa Hospital, designed as a secondary institution without tertiary specialist facilities so that it "never was quite equal when it came to funds or facilities', and where until 1993 there was never money to replace outdated equipment. ${ }^{64}$ An even more important issue on all campuses was the limited range

\footnotetext{
${ }^{57}$ From 1968 the SAMDC kept a record of race for purposes of planning but not publication.

58 SAIRR Report (Johannesburg: SAIRR, 1968), 277-8; Tobias, op. cit. (note 13), 396-7.

${ }^{59}$ SAIRR Report (Johannesburg: SAIRR, 1983), 485. Some Indian students studied in India and Cairo because of a lack of training places in South Africa.

${ }^{60}$ Interview with Dr Essop Jassat (MB, BCh, Wits, 1960), 25 Septemper 2002.

${ }^{61}$ Letter to K. Murray from Professor Krishna Somers (MB, ChB, Rand), 26 March 2003; copy given to author by Professor Somers.

62 Interview with Dr N. Maharaj, op. cit. (note 38).

63 Watts, op. cit. (note 14), I, 27-8.

${ }^{64}$ E.T. Mokgokong, 'MEDUNSA Out of the Woods', South African Medical Journal, 85, 3 (1995), 179; MEDUNSA Echo, 1993, 2. Inadequate clinical facilities meant that the British General Medical Council refused recognition of MEDUNSA qualifications.
} 
of clinical material and pattern of diseases that black medical students were exposed to in segregated, crowded wards where they saw only black patients, whilst also working solely on black bodies in anatomy and pathology. Students were forced to operate a 'selfpolicing' racial exclusion, ${ }^{65}$ and one African student at Wits considered that 'this is, was, humiliation' ${ }^{66}$ The range and frequency of pathologies varied according to race so that, as a black UCT student stated, 'keeping one away from white patients, took a chunk out of one's development and self-confidence; [I] couldn't see the [clinical] spectrum' ${ }^{67}$ Another remembered that 'coronary heart disease was, at the time, seen in white people, and we never saw it, we never knew anything about ECGs [electrocardiography]'. ${ }^{68}$ To try to offset this, a mentoring system was organised in which UCT seniors would report that 'there's a very interesting patient, come and have a look' ${ }^{69}$ Informally, sympathetic tutors might offset black students' one-sided exposure, as when at Wits 'Dr Chatgidakis would bring back specimens to the lunch hour tutorial in the pathology department to demonstrate and discuss findings' ${ }^{70}$ In contrast, the need for inclusive clinical experience for whites was acknowledged, as when Cape Town and Stellenbosch Medical Schools agreed that 'the essence of good teaching ... is that there should be available adequate clinical material ... drawn from the various racial groups comprising the South African complex'. ${ }^{71}$

The issue of professional standards was raised as soon as the segregated, medical training of black students developed. The initial fundraising appeal for the new Durban Medical School was insistent on the need for high standards and thus of meeting the single standard of qualification of the SAMDC. J.E. Viljoen, Minister of Education, therefore asserted that schooling at Durban was 'in no way inferior to that at other schools'. ${ }^{72}$ Training programmes elsewhere on the continent (at Yaba, Kano, Khartoum, or Makerere) were consciously distanced from the planned experience at Natal because of what were referred to as their early 'substandard' courses training medical auxiliaries, general doctors and assistant medical officers. ${ }^{73}$

Natal's Department of Family Practice provided a rare but short-lived instance of comparative advantage for black students where practical experience could be gained in community-oriented primary healthcare at the Institute of Family and Community Health (IFCH) run by the Karks. ${ }^{74}$ From its inception Natal had recognised that the majority of black students would go into general practice, so needed to have exposure to social, preventive and family medicine. ${ }^{75}$ Indeed, the first Dean, George Gale, considered Durban's family practice courses superior to that in any other South African medical

\footnotetext{
65 Interview with Dr Cassiem Dharsey (MB, ChB, UCT, 1963), 15 October 2007.

66 Interview with Professor K.P. Mokhobo (MB, BCh, Wits, 1957), 15 November 2002.

${ }^{67}$ UCT Health Faculty archives, submission to Internal Reconciliation Commission (IRC) by Dr A.D. (MB, ChB, 1977).

68 Interview with Dr A.A. Aboo, op. cit. (note 18).

${ }^{69}$ Interview with Dr A.A. Aboo, op. cit. (note 18).

${ }^{70}$ Letter to K. Murray from Professor K. Somers, 26 March 2003, op. cit. (note 61).

${ }^{71}$ National Archives, Cape Town, HM 312, Allocation of Hospitals for Training of Medical Students, December 1959.

72 The New Durban Medical School. A Response to the Challenge of Africa (Durban, University of Natal, n.d.), $12,28$.

${ }^{73}$ G. Gale, 'Medical Schools in Africa', South African Medical Journal, 34, 8 (1961), 713-14; A. Adeloya, Early Medical Schools in Nigeria (Ibadan: Heinemann, 1998), 9-10, 27, 37, 72, 91-3; Iliffe, op. cit. (note 27), 92-3.

74 G.W. Gale, 'The Durban Medical School', South African Medical Journal, 28,5 (1955), 437.

${ }^{75}$ New Durban Medical School, op. cit. (note 72), 33.
} 
school. ${ }^{76}$ But state refusal to continue funding an institution thought to harbour communist tendencies - because of the apartheid government's ideological conflation of social with socialised medicine - led to the closure of the IFCH in $1961 .{ }^{77}$ Within a fragmented and profoundly inequitable healthcare system, Natal medical students used their own initiative to work in local clinics, ${ }^{78}$ and participated in research projects linked to diseases rife in the area, including malnutrition and chronic infections. ${ }^{79}$ At MEDUNSA too there was involvement in health work in the nearby Soshanuve Township as well as in mobile clinics and rural hospitals. ${ }^{80}$ MEDUNSA's research agenda was shaped by the need to investigate health problems such as low birth rates experienced in local communities. ${ }^{81}$ The Transkei Medical School adopted problem-based learning within a community-based curriculum as a means to train doctors for poverty-stricken, rural conditions. ${ }^{82}$

\section{Career Development}

After six years of medical training a one-year hospital internship was compulsory for South African doctors. ${ }^{83}$ Internships were in such short supply that some Indians in the Transvaal were refused permission to take them in African hospitals, serving one with a general practitioner instead. ${ }^{84}$ In the Cape black internships were located only at Somerset, Victoria and Livingstone Hospitals ${ }^{85}$ For white junior doctors aspiring to be a specialist, internship was followed by three years as a registrar, and a further year in senior house posts, before peer evaluation to determine entry to a consultancy track. For blacks the interim period was usually longer, with openings pursued at King Edward VIII, McCord Zulu, Baragwanath and Kimberley Hospitals or overseas in Cairo or Dublin. In most cases this gave a narrower clinical experience focused on black patients and their common diseases so that a specialist career was then harder to develop. ${ }^{86}$ Indeed, the Theron Inquiry had concluded that 'Coloured graduates cannot compete on an equal footing for posts as resident doctors in teaching hospitals'. ${ }^{87}$ This was not only because of institutional barriers but because black doctors lacked role models and mentors to ease prolonged rites of passage. Whereas elite white graduates were perceived (perhaps erroneously) as having connections, money and self-confidence to realise their ambitions, able black graduates might be rebuffed by their seniors. One UCT doctor of colour recollected taking his life downstairs' following a year as a junior registrar because in 1963 the Professor of Pathology told him 'for you blacks there is no post'. As a result he sought post-graduate

\footnotetext{
76 Gale, op. cit. (note 73), 717.

${ }^{77}$ D. Yach and S.M. Tollman, 'Public Health Initiatives in South Africa in the 1940s and 1950s', American Journal of Public Health, 83, 7 (1993), 1047-8.

${ }^{78}$ UNB News, March 1985. Community health work at UNB was part of a larger, political commitment to their local people by individuals adhering to a Black Consciousness ideology.

${ }^{79}$ E.B. Adams, 'Research Achievements of the University of Natal Medical School 1951-1976', South African Medical Journal, 50, 9 (1976), 1577, 1583.

80 'Let's Talk about Health', Student Voice, 2, 1 (1988); 'Editorial: The Story of MEDUNSA', South African Medical Journal, 66, 12 (1995), 1525.

${ }^{81}$ M.A. Haynes and A.B. Lee, 'MEDUNSA and the Training of Black Doctors for South Africa', Academic Medicine, 70, 2 (1995), 117.

82 Breier with Wildschut, op. cit. (note 26), 88-9.

83 The SAMDC began internships in 1949, and in 1981 designated Sixth-year undergraduates as student interns.

${ }^{84}$ Rand Daily Mail, 28 August 1951; Star, 5 September 1951.

85 National Archives, Cape Town, HM 183, batch 1, 7 July 1952.

86 Interview with Dr N. Maharaj, op. cit. (note 38).

${ }^{87}$ South African government publication, RP 38-1976, Coloured Population, 240.
} 
specialist experience in Canada. ${ }^{88}$ It was a decade later before UCT agreed that coloured graduates should compete for posts on equal terms. ${ }^{89}$ And even at MEDUNSA there was reluctance to train African registrars to become specialists. ${ }^{90}$

A fortunate few gained hospital posts: Baragwanath offered houseman posts to African doctors as early as 1952-3; a decade later eight per cent of its full-time doctors were African, but by the end of the seventies this was only five per cent. Livingstone appointed its first black paediatrician in $1967 .{ }^{91}$ Despite some advances, however, one doctor of colour recollected the continuing micro dynamics of UCT culture during the early seventies, where coloured individuals had a 'status as second-class medical students'. ${ }^{92}$ There was 'unspoken differentiation' over access to extra tutorials, and a grooming process that 'wasn't shared', including extra tutorials, post-graduate training abroad and entry to a specialist track. Black students were denied the 'pathway to becoming an academic leader' through a 'subtle process' in which race, religion, class and language served as filters. A turning point at UCT came in 1971 when Bryan Kies was chosen as a registrar but recollected that UCT's Professor of Medicine, Stuart Saunders, asked him not to talk to the newspapers, as this kind of career advancement for Coloureds wasn't apartheid government policy. ${ }^{93}$

Conditions of service were discriminatory. Accommodation and facilities for black staff in hospitals was inferior, as at Groote Schuur Hospital in Cape Town, ${ }^{94}$ whilst in the country more generally few changing and shower rooms were attached to hospital theatres for the use of black surgeons. ${ }^{95}$ Black hospital doctors experienced discriminatory leave periods, housing subsidies and pension schemes. ${ }^{96}$ There were differential salaries for interns, registrars and medical officers with such low salaries for the latter that posts were difficult to fill during the early sixties in the Cape, whilst in the Transvaal African doctors threatened to resign over the issue. ${ }^{97}$ The situation was still inequitable during the early seventies: as interns, Coloureds and Indians earned seventy per cent and Africans sixtythree per cent of white salaries. After becoming medical officers, Africans found their final salary was less than the starting salary of whites. ${ }^{98}$ In state employment, too, Coloureds or 'Asians', earned seventy to eighty-one per cent and Africans sixty-five to seventy-six per cent of the salary of white colleagues. ${ }^{99}$ Belatedly in 1974, the Council of the Medical Association of South Africa stated that the South African Medical Journal would not accept advertisements of posts with discriminatory conditions. ${ }^{100}$

During the late sixties and early seventies there was publicity on African doctors taking up senior posts abroad because their promotion in South Africa was blocked because of

${ }^{88}$ Interview with Dr C. Dharsey, op. cit. (note 65).

${ }^{89}$ UCTAA, Minutes of Board of Faculty of Medicine, 4 Septemper 1973, memorandum to Theron Commission.

90 M.S. Mokgokong: inaugural address, MEDUNSA Newsletter, September 1997, 7.

91 SAIRR Reports (Johannesburg: SAIRR, 1967), 300; Horwitz, op. cit. (note 3), 108.

92 Pick, op. cit. (note 4), 84.

93 UCT Health Faculty Archives, submission to IRC by Bryan Kies (MB, ChB, 1971).

94 Digby et al., op. cit. (note 41), 130.

95 RP 38-1976, Coloured Population, paragraph 10.60.

${ }^{96}$ L. Baldwin-Ragaven, J. de Gruchy and L. London, An Ambulance of the Wrong Colour: Health Professionals, Human Rights and Ethics in South Africa (Cape Town: University of Cape Town Press, 1999), 41.

${ }^{97}$ National Archives, Cape Town, HM 323, report 1962; Cape Director of Hospitals Report (Cape Town: Cape Provincial Government, 1960), paragraph 18; Monamodi, op. cit. (note 3), 355.

98 SAIRR Report (Johannesburg: SAIRR, 1971), 308.

${ }^{99}$ M. Horrell, The African Homelands of South Africa (Johannesburg: SAIRR, 1973), 16.

100 'Editorial', South African Medical Journal, 48, 6 (1974). 
the racially charged issue of senior black doctors giving instructions to white staff. ${ }^{101}$ However, without public awareness the medical brain drain had begun earlier: amongst the dozen black doctors graduating at Wits in 1949, for example, two-thirds left South Africa. ${ }^{102}$ One black UCT graduate later expressed the rationale for his emigration: 'I was never made to feel I had potential. I only discovered I had potential when I went to another country'. ${ }^{103}$ This leakage of talent was one reason adduced for a low black fellowship in the South African College of Medicine. ${ }^{104}$

The emigration issue has continued to have huge relevance, although South African evidence suggests lower rates of emigration for young black doctors than for white. ${ }^{105} \mathrm{In}$ the African continent more generally, whether to emigrate or not has loomed large amongst recent medical graduates, as in the central African state of Malawi. ${ }^{106}$ Global concern continues over an ongoing medical brain drain from sub-Saharan Africa and focuses on the consequent detriment to the healthcare of source countries. ${ }^{107}$ Although South Africa has been less hard hit than many countries, the Minister of Health has lamented the outflow of scarce medical skills. ${ }^{108}$

\section{Serving 'Their Own People'}

An apartheid geography of defined racial residential zones had been created under the Group Areas Act (1950). Public bursaries to black medical students were conditional on graduating doctors setting up in racially defined areas approved by the state, thus confining private practice to ethnic communities. ${ }^{109}$ One African doctor aptly expressed this as 'service was to be remote in own areas - rural/homelands - to pay back in service'. ${ }^{110}$ Already by 1962 the distribution of black doctors broadly reflected that of the black population. ${ }^{111}$ A quarter of a century later the official Browne Commission still put forward the need for 'Asian', Coloured and black health personnel 'to serve their communities' because of 'differences in cultural, social and linguistic background'. ${ }^{112}$ That black doctors treated black patients was evident in careers. For example, Yosuf Veriava revealed that it was almost a quarter of a century after his qualification at Wits in 1968 that he was first able to treat a white patient. ${ }^{113}$

On opening the Durban Medical Faculty Dr Karl Bremer, Minister of Health, had articulated apartheid ideology in stating that 'This medical school has a great opportunity

\footnotetext{
101 SAIRR Reports (Johannesburg: SAIRR, 1969), 235; (1973), 352.

102 E-mail to author from Professor K. Somers, 21 December 2007.

103 UCT Health Faculty Archives, submission to IRC by Dr J.V. (MB, ChB, 1982).

104 RP 38-1976, Coloured Population, 239.

105 Breier with Wildschut, op. cit. (note 26), 38, 93.

106 C.L. Wendland, A Heart for the Work. Journeys through an African Medical School (Chicago, Il.: University of Chicago Press, 2010), 155-8.

107 A. Hagopian et al., 'The Migration of Physicians from Sub-Saharan Africa to the USA', Human Resources for Health, 2, 17 (2004), 1-10: Breier, with Wildschut, op. cit. (note 26), 18-19.

108 'We must end doctor brain drain' (Minister of Health), [South African] Citizen, 20 August, 2002.

${ }^{109}$ L. Kuper, An African Bourgeoisie (New Haven, Ct.: Yale University Press, 1965), 239.

110 E-mail to author from Professor K. Mokhobo, 15 November 2002.

111 South African government papers, RP 59/1962, Report into High Cost of Medical Services and Medicines, 69; G.R. Beaton, A.D. Mendelow and D.E. Bourne, 'A Career Study of Medical Graduates of the University of Witwatersrand, 1925-1972', South African Medical Journal, 49, 11 (1975), 2134-5.

112 South African government papers, RP 61/1986, Third Interim Report of Commission of Inquiry on Health Services, Professional Matters, 45-6.

113 Baldwin-Ragaven et al., op. cit. (note 96), 176-8.
} 
to evolve a training which will specially fit its graduates to serve the needs of its own people'. ${ }^{114}$ Even progressives such as Dr Henry Gluckman also envisaged 'non-European' doctors 'serving the health needs of their own people' or serving 'their own people in various ways' ${ }^{115}$ whilst the National Health Services Commission Report of 1944 foresaw a new medical school for blacks producing doctors to staff health centres whose patients would largely be Africans and Coloureds. ${ }^{116}$ Some individuals, like Jeanette Morupi who studied at MEDUNSA, shared this mind set, stating that she was 'motivated to choose a career where I could do something to help my black brothers and sisters'. ${ }^{117}$ But less than one-third amongst a sample of UNB students referred to opportunities to serve their own people (and/or of serving humanity) as their original career motivation. ${ }^{118}$ Early UNB students had a distinctive training in social medicine but were suspicious of this, fearing second-rate status because it set their training apart from the white model ${ }^{119}$ Both MEDUNSA's medical training and that at the University of Transkei emphasised rural community health care. ${ }^{120}$

Government medical posts reinforced separate development in being located in densely populated black areas. In 1962 Dr M.V. Gumede was made Zululand District Surgeon; ${ }^{121}$ two years later five such part-time posts were located in the Transkei and Ciskei, whilst by 1967 four out of the seven posts were still in the Transkei. ${ }^{122}$ A Department of Bantu Administration and Development circular in 1969 directed graduating African doctors to the 'homelands' then being created, which allegedly offered 'excellent opportunities for Bantu medical practitioners'. A UNB medical student confirmed that 'most doctors from here go to the homelands'. ${ }^{123}$ Indeed, there were seventy African doctors there in 1969 , growing to eighty-four by $1975 .^{124}$ The newly created Bantustan health services had many problems for practitioners including those of language, ${ }^{125}$ but also offered opportunities to become part of a new administrative elite, as when the first African specialist physician, Dr K.P. Mokhobo, became Bophuthatswana's 'energetic and visionary' Minister of Health. ${ }^{126}$

Virtually all the earliest Wits black medical graduates went into general practice, setting up in townships such as Duncan Village, New Brighton, Galeshewe, or Lady Selborne. ${ }^{127}$ One African doctor expressed the rationale as 'Private practice $=$ more freedom and better income'. ${ }^{128}$ This was similar to the motivation and career path of East African doctors at

\footnotetext{
114 Quoted in Monamodi, op. cit. (note 3), 327.

115 [South African] Hansard, 61 (1947), 6203; Hansard, 65 (1948), 2547.

116 University of York, Borthwick Institute of Historical Research, Gale Collection, Gale papers on national health service, $1940 \mathrm{~s}$.

117 'Three Top Twenty Students for MEDUNSA', MEDUNSA Echo, July 1991

118 Watts, op. cit. (note 14), 1, Table 1.

119 Noble, 'Medical Education', op. cit. (note 3), 565-8.

120 SAIRR Report (Johannesburg: SAIRR, 1987), 486; Breier with Wildschut, op. cit. (note 26), 78

121 SAIRR Report (Johannesburg: SAIRR, 1962), 171.

122 SAIRR Report (Johannesburg: SAIRR, 1965), 286; (1968), 278.

123 A. Ratsela, 'Aspects of General Practice', UNB News, 1 (1980), 27.

124 SAIRR Reports (Johannesburg: SAIRR, 1972), 409; (1976), 382.

125 See A. Digby, 'The Bandwagon of Golden Opportunities'? Healthcare in South Africa's Bantustan Periphery', South African Historical Journal (December 2012).

126 Bophuthatswana Report on Health and Social Welfare, 1980, A1, A3.

127 Members of 1946-51 cohorts (named in K.P. Mokhobo, 'African medical pioneers', MEDUNSA Yearbook, 1997-8, op. cit. (note 24), 181-2), were collated with entries in B. Crowhurst (ed.), Medical Directory of South Africa (Durban: Knox Publishing, 1960).

${ }^{128}$ E-mail to author from Professor K.P. Mokhobo, 15 November 2002.
} 
the time. ${ }^{129}$ Amongst a sample of Natal graduates, private practice was viewed both as a positive alternative to the racially discriminatory pay of a hospital post and as a means 'to earn more money'. ${ }^{130}$ Hidden financial pressures dictating career choice originated in the bursary loan that had financed medical school, which meant black doctors became obligated to repay money. ${ }^{131}$

George Gale had warned that 'it is a temptation ...t to assume That ...there are tremendous opportunities for African doctors among their own people'. ${ }^{132}$ Indeed, a study found that the typical township general practitioner (GP) suffered from overwork, lack of professional access to hospitals, and frustrating restrictions in treating patients, whose loyalty to alternatives (notably indigenous medicine) delayed therapy, whilst their impoverishment limited drug prescription. ${ }^{133}$ William Pick, a doctor of colour, set up a family practice in a designated group area - Tervlei - where the hours were 'long' and the workload 'enormous', with only one day taken off during the first two years of practice. ${ }^{134}$ In this kind of high-traffic practice in the working-class sector of the medical market there were clear parallels with earlier black doctoring in the American South during the depressed 1930s, where the doctor also had 'a time-consuming, demanding job'. ${ }^{135}$

Continuing shortages of African practitioners tempted the more numerous Indian practitioners into African township practices despite its illegality under the Group Areas Act. Official action threatened prosecution and notice to leave, although official second thoughts permitted such practice if doctors from the community were unavailable. ${ }^{136}$ Many Indian doctors were advantaged by their family's commercial background, with connections to local businesses as well as knowledge of accounting and debt collection. But conditions for practice in a very unequal and impoverished society were difficult, as Dr Anvir Adam recollected:

I tried to attend anyone who required my assistance .... Many of my colleagues like myself have rarely sent accounts to patients when they were unable to pay.... Diseases [were] mainly related to undernutrition, preventable infectious diseases eg. gastro-enteritis, other water-borne diseases related to poor sanitary conditions.... There was never enough money for a good health system in the semi[rural] and rural areas where most of the disadvantaged had to go - the 'homelands'. ${ }^{137}$

For Indian medical women there was the possibility of occupying a market niche in offering a distinctive all-female practice, as did Dr Moseda Ismail in Durban. ${ }^{138}$ Nevertheless, Indian practitioners felt apartheid restricted them. 'Because of the Group Areas Act we could not live or practice where we wanted to - everything was governed by permits'. ${ }^{139}$ And 'we had no alternative but to start a private practice of some sort. Ill equipped and dark and dingy premises. No help from banks to finance our practices'. ${ }^{140}$

\footnotetext{
${ }^{129}$ Iliffe, op. cit. (note 27), 109-10.

${ }^{130}$ Watts, op. cit. (note 14), II, 31. This was based on a stratified sample of eighty Natal graduates taken from the Medical Register.

${ }^{131}$ Ratsela, op. cit. (note 124), 25-6; Watts, op. cit. (note 14), II, 11.

132 William Cullen Library, SAIIR papers, AD 1715a, 'The African Doctor' delivered to National Council of Women of South Africa, 1 May 1952.

133 Watts, op. cit. (note 14), II, 22-3, 31.

134 Interview with Professor W. Pick, op. cit. (note 31); Pick, Slave, op. cit. (note 4), 122-4.

135 J.D. Stoeckle and G.A. Wright, Plain Pictures of Plain Doctoring (Cambridge, Mass.: MIT Press, 1985), 68.

136 SAIRR Report (Johannesburg: SAIRR, 1970), 261-3.

137 Personal communication from Dr A. Adam, 2 August 2003.

138 E-mail to author from Professor K. Somers, 19 October 2007.

${ }^{139}$ Personal communication to author from Dr A. Adam, 2 August 2003.

${ }^{140}$ E-mail to author from Dr A. Adam, 15 November 2002.
} 
In her Durban practice Dr Gonarathnam Goonam described the frequency with which a general practitioner dealt with patients whose illnesses were derived from personal trauma resulting from apartheid group areas and population registration legislation. ${ }^{141}$

Black general practitioners' access to their patients in hospitals was problematic. 'Native Doctor Set Hospital Board a Problem' read a newspaper headline in 1948 in prefacing discussion of anxieties provoked at Grey Hospital in King William's Town, where one of Wits' first African medical graduates had applied to be an honorary surgical staff member. ${ }^{142}$ The Cape Provincial Administration later clarified its policy by stating that, although it did not exclude 'non-European' doctors, hospital medical superintendents could still bar individuals. ${ }^{143}$ Responses to its ensuing hospital circular revealed discriminatory practices with conditional access imposed on black doctors, and prejudicial attitudes including one superintendent who viewed an African doctor as a 'troublemaker' ${ }^{144}$ Continuing anxiety about black doctors issuing instructions to white nurses and/or white junior medics, thereby subverting the established racial hierarchy of apartheid South Africa, resulted in black practitioners being pressurised to hand over patients to white colleagues in smaller, country or suburban hospitals. ${ }^{145}$

\section{Trajectories For Medical Women}

Early graduation returns from medical schools seldom had a gendered breakdown. Yet women were amongst the first black doctors: Mary Susan Malahelela (later Xakana) graduated at Wits in 1947 and Rawa Patel at UCT in the following year. ${ }^{146}$ However, Wits remained overwhelmingly male, with only one in five female medical students by 1959. ${ }^{147}$ UNB also had few women, with thirty out of 161 admissions between 1951 and $1955,{ }^{148}$ whilst between 1957 and 1973 only one in seven of its graduates were women. Amongst this small minority Indians greatly outnumbered Africans. ${ }^{149}$ Over the longer term (1957-94), the Natal Medical Faculty had less than one in four women (twenty-three per cent) amongst its graduates, ${ }^{150}$ although MEDUNSA did rather better with thirty-six per cent. ${ }^{151}$

A female student might feel double pressure from her gender and her race, and one UCT graduate woman commented 'I had not just to be good, I had to be better than good - I wanted to show them that I was equal or better' ${ }^{152}$ Despite this kind of ambition, in Natal cohorts between 1951 and 1970 only thirty-one per cent of females graduated compared to forty-six per cent of males. ${ }^{153}$ Vanessa Noble has argued that gender inequalities at

\footnotetext{
141 G. Goonam, Coolie Doctor, ch. 18 (Durban: Madiba Press, 1991), 19.

142 Cape Argus, 21 February 1948.

143 National Archives, Cape Town, HM 183, batch 1, statement 7 July 1952.

144 National Archives, Cape Town, HM 322, Access of Non-European Doctors to Provincial Hospitals, 1961.

145 SAIRR Report (Johannesburg: SAIRR, 1973), 352; S. Marks, Divided Sisterhood. Race, Class and Gender in the South African Nursing Profession (Johannesburg: Witwatersrand University Press, 1994), 141.

146 A. Digby, 'Some Early Black Doctors - A Very Politically Active Cohort, 1941-54', South African Medical Journal, 97, 8 (2007), 577; The Cape Times, 2 February 1948.

${ }^{147}$ A. Brown and J. Barnes, 'The Medical School of the Witwatersrand - A Brief History', Adler Museum Bulletin (1997), 9; Murray, op. cit. (note 1), 174.

148 Gale, op. cit. (note 73), 440.

149 SAIRR Report (Johannesburg: SAIRR, 1974), 383.

${ }^{150}$ Noble, 'Doctors Divided', op. cit. (note 3), 3.

151 MEDUNSA Archives, graduation booklet statistics, 1985-90.

152 UCT Health Faculty Archives, evidence to IRC by Dr D.C.B (MB, ChB, 1979).

153 Watts, op. cit. (note 14), I, 37.
} 
the Natal Medical Faculty 'greatly influenced' women's lives and choices. ${ }^{154}$ Mamphele Ramphele described how she and other politicised UNB women 'learnt to be tough, insistent, persistent and to hold our own in public and private debates'. 155

Black women were in a small a minority amongst black doctors, as were all medical women in the South African medical profession where, by 1960, only ten per cent was female. ${ }^{156}$ Between 1947 - when the first black medical woman graduated - and 1981, fifty-three such women had graduated at Natal and fifteen at Wits. (This total was higher than in the competing profession of law where only thirty-three females had qualified nationwide by 1982.) Career progression of medical women was broadly similar to men: they did their internships at black hospitals and most went into township practice. For example, Mary Xakana practised as a township GP with a special interest in tuberculosis (TB) sufferers and later became a community activist. ${ }^{157}$ Despite the stereotype being of a small female minority opting for a hospital career, ${ }^{158}$ amongst a self-selected sample of UNB women almost as many opted for a specialism as for general practice. ${ }^{159}$

One early black medical woman alleged that gender stereotyping was so 'deeply entrenched' that girls were expected to teach or nurse but not to doctor. ${ }^{160}$ Such external expectations might be internalised. ${ }^{161}$ Some overcame this: Rawa Patel stated that 'Ever since I was a little girl I wanted to be a doctor', ${ }^{162}$ whilst Ozma Mbombo reflected that 'It's a good, good feeling to have achieved something you've wanted to do so long!' after her tenacious progression through nursing and teaching to graduate as a medic. ${ }^{163}$ Such ambition helped withstand what Bozzoli has termed a 'patchwork quilt of patriarchies', ${ }^{164}$ and for medical women these involved the institutionalised sexism of the medical school with demeaning comments by lecturers, and a later discriminatory hospital environment, as at King Edward VIII Hospital with its sexist harassment, female professional invisibility and unequal salaries and benefits. ${ }^{165}$ Women also encountered the wider power differentials of patriarchal African and Indian cultures involving practical and psychological barriers to professional success. ${ }^{166}$ Indeed, elsewhere on the continent only a handful of African women qualified because of early gendered restrictions on school science lessons leading to low recruitment to medical school. ${ }^{167}$ Within a socially conservative medical profession in South Africa, young medical women

154 Noble, 'Doctors Divided', op. cit. (note 3), 262-3, 296.

155 M. Ramphele, 'The dynamics of gender within black consciousness organisations: a personal view', in N.B. Pityana et al. (eds), Bounds of Possibility: the Legacy of Steve Biko and Black Consciousnes (Cape Town: David Philip, 1991), 219-20.

${ }^{156}$ E. Walker, "“Conservative Pioneers": The Formation of the South African Society of Medical Women', Social History of Medicine, 4 (2001), 483-506.

${ }^{157}$ E. Kuzayo, Call me Woman (Johannesburg: Picador Africa, 2004), 283-5.

158 Breier with Wildschut, op. cit. (note 26), 32.

${ }^{159}$ Reconciliation, op. cit. (note 2), 19-58.

${ }^{160}$ Ramphele, op. cit. (note 4), 43.

161 Broun, op. cit. (note 11), 135.

162 Cape Times, 2 February 1948.

163 Weekend Argus, 15 December 1973.

164 B. Bozzoli, 'Marxism, Feminism and South African Studies', Journal of Southern African Studies, 9, 2 (1983), 140-2.

165 Van Heyningen, op. cit. (note 2); Noble, 'Doctors Divided', op. cit. (note 3), 276-7, 280, $289-90$.

166 Noble, 'Doctors Divided', op. cit. (note 3), 303; Broun, op. cit. (note 11), 212.

167 A. Patton, Physicians, Colonial Racism and Diaspora in West Africa (Gainesville: University of Florida, 1996), 192. 
discovered male power to be entrenched and institutionalised, ${ }^{168}$ so that a sample survey of registered medical women of all races in 1983 found that, because they were women, half had encountered gender discrimination and four-fifths had experienced career difficulties. ${ }^{169}$ Unfortunately, the South African Society of Medical Women - a professional organisation set up to advance and improve medical women's position through confronting professional discrimination and inequality - was perceived by black female doctors to be 'white, elitist and apolitical and consequently unable to meet the needs of black women'. ${ }^{170}$

Amongst a sample of UNB female graduates, most stated they would recommend medicine as a career for 'intelligent and ambitious young women' although a minority disagreed, citing problems in combining a medical career with marriage. ${ }^{171}$ Given these difficulties, black medical women might turn to familial networks for support. For example, Dr Beryl Peters was the sister of the first Indian doctor in Pietermaritzburg, Maurice Peters, and worked closely with him, whilst Padmini Peters, one of his two medically qualified daughters, ran her practice from her late father's medical rooms. ${ }^{172}$

\section{Political Activism}

Institutionalised racism resulted in some political activism, despite Kuper's comment that 'The African doctor, of all professionals, is probably in the best position to avoid political involvement'. ${ }^{173}$ At the beginning of the apartheid era older moderate medical leaders had withdrawn from the political frontline to devote themselves to their medical practices, although amongst a younger generation some pursued radical activism. ${ }^{174}$ Their highly politicised attitudes were reported in 1955 at Victoria Hospital, Lovedale where Dr Cooper, as medical superintendent, disapproved of 'the very great activity shown by African medical practitioners especially in undesirable political movements' such as the African National Congress (ANC). Cooper foresaw that 'our hospitals [will] develop into breeding grounds for racial strife'. Even worse, in his opinion, was that 'two or three African interns had a definitely unfavourable influence on student nurses'. Cooper insisted on black candidates for junior hospital posts providing a written undertaking to take no active part in politics, thereby causing their numbers to plummet. ${ }^{175}$

Repression by the early apartheid state resulted in the loss of scarce medical skills as politicised black doctors were tried, banned or went into exile. ${ }^{176}$ Following the banning of the ANC and the Pan African Congress in 1960, political activity slumped, before renewed activism occurred in 1969 with the creation of a South African Students Organisation (SASO) informed by Black Consciousness Movement (BCM) ideology. The universalist,

\footnotetext{
168 E. Walker, 'The South African Society of Medical Women, 1951-1992: Its Origins, Nature and Impact on White Women Doctors' (unpublished Ph.D. thesis, University of the Witwatersrand, 1999), 7-9, 26-33.

169 A.J. Brink et al., 'Women Doctors in South Africa. A Survey of Their Experience and Opinions', South African Medical Journal, 80, 12 (1991), 561-6: 565.

${ }^{170}$ L. Walker, “'Since Male Doctors were Pushing us Aside, We Had to Elbow Our Way Through”. A History of the South African Society of Medical Women', South African Medical Journal, 87, 11 (1997), 505-7: 1507.

171 Watts, op. cit. (note 14), II, 41-2.

172 University of KwaZulu-Natal, Alan Paton Collection, PC 138, Dr Maurice Peters' Collection.

173 Kuper, op. cit. (note 109), 244.

174 A. Digby, 'Early Black Doctors in South Africa', Journal of African History, 46 (2005), 427-54; Digby, 'Some Early Black Doctors', op. cit. (note 146), 577-80.

175 National Archives, Cape Town, HM-M100, employment of non-Europeans, report 14 April 1955.

176 Digby, 'Early Black Doctors', op. cit. (note 174), 444.
} 
humanist values of BCM synchronised with black students' medical aspirations. For many, but not all black medical students, a culture of opposition became inseparable from medicine, with widespread political activism evident especially amongst Africans at UNB by the 1970s (with support for SASO) and in the 1980s (with support for the United Democratic Front and the ANC. ${ }^{177}$ This was enabled by a comparatively liberal campus, ${ }^{178}$ and by the fact that Indian, African and Coloured students had been brought together in a way that negated apartheid separatism. ${ }^{179}$ SASO's first office at UNB was situated in the medical hall of residence because its first president, Steve Biko, was enrolled in the medical faculty. Biko was dismissed in 1972 after privileging the political struggle over his medical career, as indeed had the first cohorts of South African educated black doctors. ${ }^{180}$ But a fellow activist recollected the importance of the SASO subculture, and how Biko and fellow SASO leaders provided 'pride, hope and things to aspire towards' ${ }^{181}$ After SASO was banned in 1977, Natal's Medical Students Representative Council published the radical UNB News, which revealed simmering discontent over exclusions as well as high failure rates, and with student boycotts occurring in 1977, 1980, 1982, 1984 and 1986. ${ }^{182}$ The News (itself later banned), commented that 'remarks passed by some staff instil fear and uncertainty'. ${ }^{183}$ Indeed, an earlier inquiry in 1975 had found a politicised student body wary of the white staff, viewing their perceived paternalism as unacceptable, and 'suspicious of motives' ${ }^{184}$ At MEDUNSA the students accused the largely Afrikaner staff of racism, even of terrorising them, ${ }^{185}$ with unexpected elements in examinations viewed as those of an 'enemy who is out to sabotage'. ${ }^{186}$ The MEDUNSA campus was disrupted by boycotts during 1983 and $1989,{ }^{187}$ and any easing of racial tension had to await the post-apartheid appointment of the first black vice-chancellor. ${ }^{188}$

SASO was male-dominated; its female members on the Durban campus left its patriarchal assumptions unquestioned, although they shared its opposition to racial domination. ${ }^{189}$ In contrast, at MEDUNSA there was an active women's group in the black consciousness-informed Azanian People's Organisation. ${ }^{190}$ Amongst politically active medical women more generally were Gonarathnam Goonam (active in the Indian Congress of Natal), Ansuya Singh of the King Edward VIII Hospital, Margaret Chuene Mncadi (an ANC activist who served a prison sentence before going into exile), and Pascal Ngakane

\footnotetext{
177 Campus members of the Zulu organization, Inkatha, were perceived by activist SASO members as supporters of the KwaZulu Bantustan, and hence supporters of the apartheid regime.

${ }^{178}$ M. Ralekhetho, 'The black university in South Africa: ideological captive or transformative agent?', in J.D. Janzen (ed.), Knowledge and Power in South Africa. Critical Perspectives across Disciplines (Johannesburg: Skataville, 1991), 106, 108.

179 Noble, 'Doctors Divided', op. cit. (note 3), ch. 3, passim, 117-68.

180 Digby, 'Early Black Doctors', op. cit. (note 174), 427-54.

${ }^{181}$ M.W. Makgoba, Mokoko: The Makgoba Affair (Florida Hills: Vivlia Publishers, 1997), 33.

182 UNB News, 7 March 1985.

183 Ibid.

184 Watts, op. cit. (note 14), 40.

185 'Heyl - The Dean That Was', Student Voice(1992).

186 MEDUNSA Archives, C4, 'Stormy Year for Azaso Campuses', SASPU National, 1983; 'MEDUNSA out of the Woods', South African Medical Journal, 85, 3 (1995), 179; S. Badat, 'The expansion of black tertiary education, 1977-90: reform and contradiction', in E. Unterhalter et al. (eds), Apartheid Education and Popular Struggles (London: Zed Books, 1991), 88.

${ }^{187}$ MEDUNSA Archives, graduation ceremony preface, op. cit. (note 12), 3.

188 Haynes and Lee, op. cit. (note 81), 115.

${ }^{189}$ Ramphele, op. cit. (note 155), 214-5.

190 William Cullen Library, Delmas Treason Trial papers, J4.1.4 AA B6, Proposals 2 November 1983.
} 
who was imprisoned on Robben Island from 1964 to 1967. Studying at UNB, Mamphela Ramphele was one of the BCM founders, and suffered internal banishment in Tzaneen from 1977 to 1984. Another at Natal was the later ANC Minister of Health, Nkosazana Dlamini-Zuma, a member of the banned ANC who fled in 1976 and qualified in exile. Amongst male medical activists were Sibongiseni Dhlomo (imprisoned on Robben Island for terrorism during 1987-91), ${ }^{191}$ and 'Chota' Motala (an accused in the 'Treason Trial' of 1956-60, later banned during 1963-8)

Apartheid might radicalise even the apolitical. Dr Anvir Adam stated that he 'was detained for the stance I took against human rights abuses' and that 'this was all to do with the disadvantaged state and glaring imbalances between white and non-whites. I am not a politician'. ${ }^{192}$ Unlike black lawyers - with their highly visible human rights actions in court - many doctors were valuable precisely because they operated below the horizon of public visibility. Communities co-opted selected GPs to look after individuals injured in 'the struggle'; most gave free treatment whilst keeping minimal documentation, thus avoiding admission to a hospital where security services would pursue injured activists. ${ }^{193}$ In Pietermaritzburg Drs Chota Motala and Maurice Peters treated without charge the Indian women injured during passive resistance campaigns. ${ }^{194}$ In later apartheid years the struggle also encompassed labour activism, with MEDUNSA medical students boycotting classes in solidarity with striking hospital workers. ${ }^{195}$ In Cape Town Dr Norman Maharaj described himself acting as 'a political being, as an agitator, as a militant' in organising general hospital workers into an independent trade union. ${ }^{196}$

The activism of white medical students had limited success in improving the situation of black colleagues. Wits students created scholarships, raised the issue of funding internships for Indians with provincial administrations ${ }^{197}$ and protested against the prohibition of black students rotating to the J.G. Strijdom or Johannesburg Hospitals, showing solidarity in refusing to be placed there. ${ }^{198}$ In earlier years the UCT Medical Student Council made only ineffectual efforts to ameliorate black students' problems by raising issues involving discrimination, but then accepting that apartheid policies prevented their resolution. ${ }^{199}$ Later, UCT medical students took a more active role in moves towards desegregation, focusing on changing the segregated arrangements at the training hospital of Groote Schuur. ${ }^{200}$

\section{Reconciliation and Transformation}

From the 1980s institutions showed signs of change in their attitudes towards the training of black health professionals. In 1980 the Dean of Wits Medical School demanded a radical equalisation programme together with affirmative action to bridge gaps in medical

\footnotetext{
191 G.M. Gerhart and T. Karis (eds), From Protest to Challenge (Palo Alto: Hoover Institution, Stanford, 1977), IV; E-mail to author from Professor K. Somers, 21 December 2007; Reconciliation, op. cit. (note 2), 20.

192 E-mail to author from Dr A. Adam, 15 November 2002.

193 Baldwin-Ragaven et al., op. cit. (note 97), 65.

194 University of KwaZulu-Natal, Alan Paton collection, PMB 01 APB1; Maurice Peters collection, PC 138/2/1/1/1/1-5.

195 MEDUNSA Echo, August 1992, 1.

196 Interview with Dr Maharaj, op. cit. (note 38).

197 National Archives, Cape Town, HM 1183, batch 1, letter of 24 Septemper 1951.

198 Shear, op. cit. (note 1), 218-19: Browde et al. (eds), op. cit. (note 2), 26.

199 Inyanga, October 1951, 8; October 1957, 10-14; October 1959-60, 116-7; November 1962, 144; $1964,98$.

200 Digby et al., op. cit. (note 41), 126-7.
} 
training, ${ }^{201}$ whilst a few years later Dr Marian Jacobs, a later Dean of the UCT Health Sciences Faculty, indicted the apartheid training system for producing 'rich white doctors' for the white urban sector. ${ }^{202}$

Each of the two historically white training institutions later held formal internal reconciliation processes to acknowledge institutional collusion with apartheid and failure to challenge discriminatory policies, or address unequal opportunities. Wits noted that senior staff acquiesced in silence over institutionalised discrimination, that black medical students and staff had been humiliated, made to feel inferior and inadequate, treated insensitively, denied advancement, generally neglected and made to feel either 'incidental and peripheral' or 'outsiders in a hostile environment'. Whilst acknowledging individual and collective protests it judged that the faculty as a whole had 'colluded with racial apartheid and enforced racial discrimination'. ${ }^{203}$ And at UCT individual submissions from past black medical students were eloquent about what one termed 'a culture of abuse' and another 'a daily feeling of humiliation' in their training. ${ }^{204}$ Others testified to their training as involving being 'cheated', made to 'feel inferior', or being part of an 'invisible group', with too many staff seen as patronising, paternalistic, insensitive or condescending. One encapsulated the impact of UCT's permit system as having been that 'you never felt accepted, or that you belonged there'. ${ }^{205}$

After the apartheid government lifted its severe restrictions on black students' ability to train at these two historically white universities in 1986, their applications increased, ${ }^{206}$ and by 1999 black medical students outnumbered white students at Wits and UCT. ${ }^{207}$ The historian is able to track the transformation of UCT's demographic profile: from 1986 to 1991 African and Indian applications grew significantly, with the first African medical graduate in 1990. Increasingly, African applicants had experienced tertiary education before UCT, so nearly all graduated successfully, although those entering directly from school fared more poorly. ${ }^{208}$ UCT affirmative action assisted black students who had had inferior school education. In 1993 African students were admitted under a Medical Academic Support Programme and completed three pre-clinical years in four, whilst benefiting from additional tutorials and non-academic mentoring and bursaries. ${ }^{209}$

The female entry steadily increased so that, by 1993, women from all races made up fifty-six per cent of the first year and in the following year thirty per cent of black admissions were female. ${ }^{210}$ Less positively, however, after 1999 black women formed a lower proportion of graduations than enrolments, indicating poorer comparative performance than black men. ${ }^{211}$ This contrasted with the USA experience where, from the

\footnotetext{
201 SAIRR Report (Johannesburg, SAIRR, 1980), 373.

202 SAIRR Report (Johannesburg: SAIRR, 1986), 783.

203 J. Browde et al., op. cit. (note 2).

204 UCT Health Faculty Archives, submission to IRC by Dr G.P. (MB, ChB, 1986) and Dr W. (MB, ChB, 1965).

205 UCT Health Faculty Archives, submission to IRC by Dr J.V. (MB, ChB, 1982).

206 UCTAA, box 7, minutes of Board of Faculty of Medicine, 9 May 1989.

207 Breier with Wildschut, op. cit. (note 26), 25.

208 UCTAA, box 7, minutes of Board of Faculty of Medicine, 19 Septemper 1990.

${ }^{209}$ UCTAA, box 8, minutes of Board of Faculty of Medicine, report on admissions for 1993.

210 UCTAA, box 8, minutes of the Board of the Faculty of Medicine, report on admissions for 1993; R.P. Colborn, A.P. Kent and B. Leon, 'The Changing Medical Student Population at the University of Cape Town', South African Medical Journal, 85, 4 (1995), 256.

211 Breier with Wildschut, op. cit. (note 26), 53-4.
} 
seventies to nineties, female black medical students had a faster growth than black males in graduating physicians and in the award of MD degrees. ${ }^{212}$

The post-apartheid period stimulated institutions and individuals to make sense of their past identities. There were broadly comparable experiences for black medical students, whether studying at black or historically white institutions. ${ }^{213}$ Whilst the latter establishments made symbolic acts of restitution, the former grappled with the need to find a satisfactory post-apartheid identity. That of UNB became an apartheid survivor, ${ }^{214}$ triumphing over unhappy memories of conflicts between a white administration and a black undergraduate body. ${ }^{215}$ MEDUNSA's earlier functional identity of servicing the 'homeland' populations with health workers was replaced by a new selfidentity as 'a pioneer of community-based tertiary education'. 216

\section{Reflections}

In 1980 Philip Tobias laid the blame for a 'scandalously low percentage of new doctors in the majority sector of the population' squarely on the apartheid state. ${ }^{217}$ However, the received record of the apartheid years frequently ignored racial differences, so that a glaring shortfall in African doctors obscured the pressing need for more doctors of colour. One of the more beneficial ironies of apartheid policy was a substantial growth of Indian doctors. This was a group inadvertently benefiting from an inequitable system, as had black nurses. ${ }^{218}$ Within a central apartheid policy of separate group development, placing black medical students of different ethnicities side by side on campus was anomalous but was an effective strategy of divide and rule. Racist medical training with its abuse of human rights thus fractured a common sense of identity and status. Racial tensions between black doctors on campus have seldom been discussed in post-colonial and postapartheid discourse so that a default view of solidarity has prevailed. Recently both A. Burton and V. Noble have emphasised the need for complex analyses focusing on alternative and selective memory production. ${ }^{219}$ Certainly, stressed relationships between African and Indian students existed at UNB over issues such as differential failure rates, ${ }^{220}$ whilst confrontation at MEDUNSA involved African accusations of anti-social Indian cliques. $^{221}$ Admission of a few white undergraduates at MEDUNSA in 1995 also led to

\footnotetext{
212 Moskowitz, op. cit. (note 55), 75.

213 Truth and Reconciliation Commission of South Africa (Cape Town, 1998), IV, paragraphs 63 and 58.

${ }^{214}$ University of Natal Medical School. A Centre of Excellence in Africa (Durban: Faculty of Medicine, 1998), 6-7. In 2004 the University of Natal merged with the University of Durban Westville to become the University of KwaZulu-Natal.

${ }^{215}$ Reconciliation, op. cit. (note 2), contributions by Drs K.P. Mlisana, M.M.R. Belle, S.C. Moodley and B.T. Naidoo.

216 'Message from VC', in MEDUNSA 20 Years, op. cit. (note 22), 2. In 2005 MEDUNSA merged with the University of the North to form the University of Limpopo.

217 Tobias, op. cit. (note 13), 398.

${ }^{218}$ Marks, op. cit. (note 145), 166-7. During the post-apartheid years admissions to medical schools were adjusted so that the entrance bar for Indians was set as high as for whites (see Breier with Wildschut, op. cit. (note 26), 22).

219 A. Burton, 'The Pain of Racism in the Making of a "Coolie Doctor"', Interventions, 13, 2 (2011), 212-35; V. Noble, 'It's Amazing How We Remember Things and Places: Memory Production and the University of Natal's Medical School' (unpublished paper, Conference on the History of Health Care in Africa, University of Basel, September 2011)

${ }^{220}$ Dr Kgotse Letslape at the 50th anniversary banquet, quoted by Noble, 'Doctors Divided', op. cit. (note 3), 18.

221 'Racism Rife on Campus', Student Voice, 1988; Z. de Mott, 'I Write What I Like', Student Voice, 1992.
} 
anxieties amongst black students that they would be deprived of what limited opportunities existed. ${ }^{222}$ For black women patriarchal prejudice reinforced racialism and was a major factor in the considerable difference between women's and men's progress in translating enrolments into graduations.

This article has explored reasons for professional marginality in experiences of class and geographical inequity (in training provision), inadequacy (in student finance), incompleteness (in clinical experience), and distortion (in career path.) Although shaped within a common discriminatory framework, the collective term of 'black doctor' has obscured diversity in experience and, for many, under-achievement in professional outcomes. Within segregated structures separate was far from equal. Burdens of isolation, alienation and humiliation had a profound psychic impact, such that one of the first African graduates at UCT reflected on his damaged self-confidence in being 'spoke down' to, concluding dramatically that 'I think my soul has been damaged'.223 Despite the potential for membership of an elite group within the black community and of a privileged professional group in wider society, most black doctors under apartheid achieved secondclass or subaltern status. They were 'marginal men and women'. ${ }^{24}$ The demeaning impact of institutionalised racial discrimination in South Africa was thus far worse than in the USA where African American physicians also faced under-representation, bias and exclusion. ${ }^{225}$ Overall the personal and professional experience of black doctors under apartheid showed a profound disconnect from the universalistic professional ideal for South Africa envisaged for black doctors by an earlier African role model, Dr A.B. Xuma. He had stated that 'Disease knows neither class nor colour ... the same knowledge and the same skill in the treatment is required'.226

222 Haynes and Lee, op. cit. (note 81), 121.

223 UCT Health Faculty Archives, submission to IRC by Dr M.N. (MB, ChB, 1990).

224 Watts, op. cit. (note 14), II, 24.

225 R.B. Baker et al., 'African American Physicians and Organized Medicine, 1846-1968: Origins of a Racial Divide', Journal of American Medical Association, 300, 3 (2008), 323-5; L.W. Sullivan and I.S. Mittman, 'The State of Diversity in the Health Professions a Century After Flexner', Academic Medicine, February (2010), $246-53$.

226 A.B. Xuma, 'Native Medical Practitioners', Leech, November (1933), 12-14. 